\title{
Penerapan Model Pembelajaran Kooperatif tipe Make a Match untuk Meningkatkan Hasil Belajar Siswa pada Pokok Bahasan Koloid
}

\author{
Penulis: \\ Hamela Sari Sitompul ${ }^{1}$ \\ Intan Maulina ${ }^{2}$ \\ Afiliasi: \\ Universitas Efarina ${ }^{1,2}$ \\ Korespondensi: \\ hamelasari@gmail.com \\ Histori Naskah \\ Submit: 99-00-9999 \\ Accepted: 99-00-9999 \\ Published: 99-00-9999 \\ This is an Creative Commons \\ License This work is licensed \\ under a Creative Commons \\ Attribution-NonCommercial 4.0 \\ International License
}

\begin{abstract}
Abstrak:
Penelitian ini bertujuan untuk mengetahui apakah hasil belajar kimia siswa yang diajarkan dengan model pembelajaran kooperatif tipe mencari pasangan (make a match) lebih tinggi daripada hasil belajar kimia siswa yang diajarkan dengan model pembelajaran konvensional. Penelitian ini dilakukan di SMA Yapim Taruna Dolok Masihul dengan populasi adalah seluruh siswa kelas XI SMA yang terdiri dari 2 Kelas. Sampel penelitian diambil secara acak berjumlah 2 kelas yang terdiri dari kelas eksperimen dan kelas kontrol. Kelas eksperimen diberi perlakuan dengan menggunakan model pembelajaran kooperatif tipe mencari pasangan (make a match) sedangkan kelas kontrol diberi perlaukan dengan menggunakan pembelajaran konvensional. Data yang diamati adalah hasil belajar kimia siswa, yang dikumpulkan melalui tes pilihan berganda sebanyak 20 soal yang terdiri dari 5 option jawaban, yang telah diujicobakan validitas, reliabilitas, tingkat kesukaran dan daya pembeda tes. Data yang diperoleh dianalisis dengan uji t, dimana sebelumnya telah diuji normalitas dan homogenitas data. Hasil belajar kelas eksperimen rata-rata pre test $(27,81 \pm 7,21)$ dan rata-rata post test $(76,88 \pm 5,70)$ dengan peningkatan hasil belajar Gain sebesar $68 \%$ sedangkan hasil belajar kelas kontrol rata-rata pre test $(22,03 \pm 6,70)$ dan rata-rata post test $(70,47 \pm 6,00)$ dengan peningkatan hasil belajar Gain sebesar $62 \%$. Uji hipotesis dilakukan pada taraf signifikansi $\alpha=$ 0,05 menggunakan uji-t satu pihak yaitu pihak kanan dimana $t_{\text {hitung }}>$ $\mathrm{t}_{\text {tabel }}(3,05>1,667139)$, yang berarti Ho ditolak dan Ha diterima. Dengan melihat hasil penelitian tersebut dapat disimpulkan bahwa hasil belajar kimia siswa yang diberi perlakuan melalui penerapan model pembelajaran make a match lebih tinggi daripada menggunakan pengajaran konvensional.
\end{abstract}

Kata kunci: Make A Match, Kimia, Koloid

\section{Pendahuluan}

Pendidikan merupakan salah satu kebutuhan pokok dalam kehidupan manusia yang memikirkan bagaimana menjalani kehidupan ini untuk mempertahankan hidup manusia yang mengemban tugas dari Sang Kholiq untuk beribadah. Oleh karena itu pendidikan memegang peranan penting dalam membangun suatu bangsa. Tanpa adanya pendidikan, perkembangan suatu bangsa tidak akan mungkin terjadi. Untuk mengolah akal pikirnya diperlukan suatu pola pendidikan melalui suatu proses pembelajaran.

Pelaksanaan pengajaran di dalam kelas merupakan tugas utama guru dan pembelajaran diartikan sebagai suatu kegiatan yang ditujukan untuk membelajarkan siswa. Permasalahan yang dihadapi dunia pendidikan kita adalah lemahny proses pembelajaran. Mata pelajaran science tidak 
dapat mengembangkan kemampuan anak berpikir kritis dan sistematis, karena strategi pembelajaran di dalam kelas.

Salah satu masalah yang dihadapi dunia pendidikan kita adalah masalah lemahnya proses pembelajaran. Dalam proses pembelajaran, anak kurang didorong untuk mengembangkan kemampuan berpikir. Proses pembelajaran di dalam kelas diarahkan kepada kemampuan anak untuk menghafal informasi; otak anak dipaksa untuk mengingat dan menimbun berbagai informasi tanpa dituntut untuk memahami informasi yang diingatnya itu untuk menghubungkannya dengan kehidupan sehari-hari. Akibatnya? Ketika anak didik lulus dari sekolah, mereka pintar secara teoritis, akan tetapi mereka miskin aplikasi.

Pembelajaran yang disampaikan dengan ceramah membuat siswa bosan, tidak bersemangat di kelas, kurang aktif dalam bertanya dan menjawab pertanyaan dan tidak berantusias saat berdiskusi kelompok dengan temannya. Oleh karena itu, peneliti membuat model pembelajaran kooperatif tipe mencari pasangan (make a match) yang membuat siswa dapat bekerja dengan teman-temannya di kelas dan melibatkan seluruh siswa dikelas.

Ilmu kimia merupakan salah satu mata pelajaran IPA yang kurang diminati, bahkan banyak siswa yang menganggap pelajaran kimia menakutkan, karena banyak siswa yang terlebih dahulu merasa kurang mampu dalam mempelajari kimia dan merasa bahwa kimia adalah pelajaran yang sulit dan membosankan. Akibatnya, hasil belajar kimia siswa relatif rendah. Selain faktor individu siswa tersebut, pengajaran kimia yang disajikan juga kurang menarik sehingga mempengaruhi rendahnya motivasi siswa dalam belajar kimia.

Salah satu kondisi yang dianggap mampu memperbaiki kondisi diatas adalah menjadikan kegiatan diskusi dengan menerapkan model pembelajaran kooperatif tipe mencari pasangan (make a match) yang diperkenalkan oleh Lurna Curran dalam Lie (2002). Make a match adalah kegiatan belajar untuk mencari pasangan kartu yang merupakan jawaban soal sebelum batas waktunya, siswa yang dapat mencocokkan kartunya akan diberi point dan yang tidak berhasil mencocokkan kartunya akan diberi hukuman sesuai dengan yang telah disepakati bersama.

Koloid merupakan salah satu pokok bahasan mata pelajaran kimia kelas XI SMA yang isi materinya bersifat abstrak. Oleh karena itu, alangkah baiknya jika siswa diajak untuk menyenangi materi ini dengan memberikan strategi, pendekatan, model, ataupun metode pembelajaran yang menarik bagi siswa.

\section{Studi Literatur}

Pembelajaran kooperatif merupakan sebuah kelompok strategi pengajaran yang melibatkan siswa bekerja secara berkolaborasi untuk mencapai tujuan bersama (Tritanto, 2009). Pembelajaran kooperatif disusun dalam sebuah usaha untuk meningkatkan partisipasi siswa, memfasilitasi siswa dengan pengalaman sikap kepemimpinan dan membuat keputusan dalam kelompok, serta memberikan kesempatan pada siswa untuk berinteraksi dan belajar bersama-sama siswa yang berbeda latar belakangnya. Belajar kooperatif dapat mengembangkan tingkah laku kooperatif dan hubungan yang lebih baik antar siswa, dan dapat mengembangkan kemampuan akademis siswa.

Arends menyatakan bahwa pelajaran yang menggunakan kooperatif memiliki ciri-ciri sebagai berikut: (1) Siswa bekerja dalam kelompok secara kooperatif untuk menuntaskan materi belajar; (2) Kelompok dibentuk dari siswa yang mempunyai kemampuan tinggi, sedang, dan rendah; (3) Bila memungkinkan, anggota kelompok berasal dari ras, budaya, suku, jenis kelamin yang beragam, dan; (4) Penghargaan lebih berorientasi kepada kelompok dari pada individu

Model pembelajaran kooperatif tipe mencari pasangan (make a match) merupakan salah satu bentuk model pembelajaran kooperatif tipe mencari pasangan (make a match) yang di dalamnya 
setiap siswa mendapat sebuah kartu (bisa soal atau jawaban), lalu secepatnya mencari pasangan yang sesuai dengan kartu yang ia pegang.

Model pembelajaran Make A Match atau mencari pasangan dikembangkan oleh Lorna Curran. Salah satu keunggulan model pembelajaran kooperatif tipe mencari pasangan (make a match) ini adalah siswa mencari pasangan sambil belajar mengenai suatu konsep atau topik dalam suasana yang menyenangkan. Model pembelajaran kooperatif tipe mencari pasangan (make a match) ini dapat digunakan dalam semua mata pelajaran dan dalam semua tingkatan usia anak didik (Retno,2010).

Model pembelajaran Make A Match atau mencari pasangan merupakan salah satu alternatif yang dapat diterapkan kepada siswa. Penerapan model pembelajaran tipe mencari pasangan (make a match) ini dimulai dari teknik yaitu siswa disuruh mencari pasangan kartu yang merupakan jawaban/soal sebelum batas waktunya, siswa yang dapat mencocokkan kartunya diberi point (Lie, 2002). Langkah-langkah dalam model pembelajaran Make A Match adalah: (1) Guru menyiapkan beberapa kartu yang berisi soal dan jawaban; (2) Setiap siswa mendapatkan sebuah kartu yang bertuliskan soal/jawaban; (3) Setiap siswa mencari pasangan yang mempunyai kartu yang cocok dengan kartunya (soal jawaban); (4) Setiap siswa yang dapat mencocokkan kartunya sebelum batas waktu diberi point; (5) Jika siswa tidak dapat mencocokkan kartunya dengan kartu temannya (tidak dapat menemukan kartu soal atau kartu jawaban) akan mendapatkan hukuman, yang telah disepakati bersama; (6) Setelah satu babak kartu dikocok lagi agar tiap siswa mendapat kartu yang berbeda dari sebelumnya. Demikian seterusnya; (7) Guru bersama-sama dengan siswa membuat kesimpulan terhadap materi pelajaran; (8) Penutup. (Lie, 2002).

Berdasarkan pemaparan di atas, masalah yang akan dikaji dalam penelitian ini adalah "Apakah hasil belajar siswa yang diajarkan dengan model pembelajaran kooperartif tipe make a match lebih tinggi dari hasil belajar siswa yang diajarkan pembelajaran konvensional pada pokok bahasan Koloid?"

Terkait dengan masalah itu, maka tujuan penelitian ini adalah untuk mengetahui (1) Untuk mengetahui hasil belajar siswa yang diajarkan dengan model pembelajaran kooperartif tipe make a match lebih tinggi dari hasil belajar siswa yang diajarkan pembelajaran konvensional pada pokok bahasan Koloid; (2) Untuk mengetahui berapa besar peningkatan hasil belajar kimia siswa melalui penerapan model pembelajaran kooperatif tipe make a match pada pokok bahasan Koloid.

\section{Metode Penelitian}

Penelitian ini dilaksanakan di SMA Yapim Taruna Dolok Masihul. Waktu penelitian dilaksanakan pada bulan Maret di kelas XI semester 2 Tahun Ajaran 2019/2020.

Populasi dalam penelitian ini adalah seluruh siswa kelas XI SMA yang berjumlah 2 kelas. Sampel adalah sebagian dari populasi. Sampel diambil secara acak (random sampling) dengan memilih 2 kelas dari 2 kelas, sehingga diperoleh satu kelas yang diberi pengajaran dengan model pembelajaran kooperatif tipe make a match dan kelas lainnya diberi pengajaran dengan model pembelajaran konvensional.

Penelitian ini bersifat eksperimen two group pretest postes design. Dalam melaksanakan penelitian ini melibatkan dua perlakuan yang berbeda antara kelas ekperimen dan kelas kontrol. tekhnik pengumpul data yang digunakan yaitu Pretes dilakukan sebelum melakukan kegiatan pembelajaran, dilaksanakan tes awal untuk mengetahui tingkat kemampuan siswa dalam materi rumus kimia dan tata nama senyawa kelas kontrol dan kelas eksperimen, dan Post tes dilakukan setelah materi koloid diajarkan kepada siswa maka dilaksanakan post tes untuk mengetahui hasil belajar siswa pada kelas kontrol dan eksperimen. 
Instrumen dalam penelitian ini berjumlah 20 item soal pilihan berganda dengan lima pilihan (option). Sebelum melakukan penelitian tes yang telah disusun terlebih dahulu diujicobakan untuk mengetahui validitas tes, reliabilitas tes, tingkat kesukaran tes dan daya pembeda tes.

Setelah data dari kelas ini diperoleh, maka langkah-langkah yang dilakukan adalah menghitung rata-rata dan simpangan baku, simpangan baku (standar deviasi) dan uji normalitas data. Uji hipotesis yang digunakan pada penelitian ini adalah uji-t yakni uji t pihak kanan.

\section{Hasil}

Sebelum kedua sampel diberikan perlakuan yang berbeda terlebih dahulu diberikan tes awal yang bertujuan untuk mengetahui kemampuan awal masing-masing siswa pada kedua kelas, serta untuk mengetahui kedua kelas tersebut terdistribusi normal dan homogen. Selanjutnya dilakukan pembelajaran yang berbeda yaitu kelas eksperimen dengan model pembelajaran kooperatif tipe Make A Match dan kelas kontrol dengan model pembelajaran konvensional. Pada akhir proses pembelajaran akan diberikan tes akhir untuk mengetahui hasil belajar siswa. Berdasarkan hasil penelitian setelah dilakukan perhitungan diperoleh rata- rata pre test untuk kelas kontrol $(22,03 \pm 6,70)$ dan kelas eksperimen $(27,81 \pm 7,21)$. Sedangkan nilai untuk post-test pada kelas kontrol $(70,47 \pm 6,00)$ dan untuk kelas eksperimen $(76,88 \pm 6,40)$.

Dari perhitungan berdasarkan data tabulasi hasil tes untuk kedua diperoleh nilai pretes dan postes kelas kontrol dan kelas eksperimen dirangkum dalam tabel 1.

Tabel 1. Hasil Perolehan Rata-rata, Standar Deviasi Pre-test dan Post-test

\begin{tabular}{|l|c|c|c|c|c|}
\hline \multirow{3}{*}{ Kelas } & \multicolumn{5}{|c|}{ Jenis Data } \\
\cline { 2 - 5 } & \multicolumn{2}{|c|}{ Pre-Tes } & \multicolumn{2}{|c|}{ Post-Tes } & \multirow{2}{*}{$\overline{\mathbf{X}}$} \\
\cline { 2 - 5 } & $\overline{\mathbf{X}}$ & SD & $\overline{\mathbf{X}}$ & SD & \\
\hline Kontrol & 22,03 & 6,70 & 70,47 & 6,00 & 48,44 \\
\hline Eksperimen & 27,81 & 7,21 & 76,88 & 5,70 & 49,07 \\
\hline
\end{tabular}

$\overline{\mathrm{X}}=$ Nilai rata-rata; $\mathrm{SD}=$ Standar Deviasi; $\Delta^{\overline{\mathrm{X}}}=$ Selisih Pre-Tes dengan Post-Tes

Pada Tabel 1 menunjukkan bahwa kelas Eksperimen memiliki peningkatan lebih tinggi sebesar 49,07 dibandingkan dengan kelas Kontrol sebesar 48,44 terhadap selisih Pre-Tes dan PostTes hasil belajar kimia siswa.

Untuk mengetahui peningkatan hasil belajar siswa maka dari data pre-test dan post-test yang diperoleh kemudian dihitung untuk mendapatkan data gain. Berdasarkan hasil penelitian setelah dilakukan perhitungan dari data gain diperoleh rata-rata kelas kontrol $(0,62 \pm 0,088)$ dan untuk kelas eksperimen $(0,68 \pm 0,085)$.

Setelah diketahui bahwa data terdistribusi normal dan homogen maka dapat dilakukan uji hipotesis dengan menggunakan uji statistik uji t satu pihak, yaitu pihak kanan. Uji ini untuk mengetahui apakah hipotesis dalam penelitian ini diterima atau ditolak. Kriteria pengujian jika $t_{\text {hitung }}>t_{\text {tabel }}$ maka hipotesis alternatif diterima dan hipotesis nihil ditolak. Data hasil uji hipotesis seperti pada tabel 2 dibawah ini: 
Tabel 2. Hasil Uji Hipotesis Data Post Test

\begin{tabular}{|c|c|c|c|c|}
\hline \multicolumn{2}{|c|}{ Data Kelas } & $t_{\text {hitung }}$ & $t_{\text {tabel }}$ & Keterangan \\
\hline Eksperimen & Kontrol & & & \\
\hline $\begin{array}{l}\bar{X}=76,88 \\
\mathrm{SD}=5,70 \\
\mathrm{~S}^{2}=32,00\end{array}$ & $\begin{array}{l}\bar{X}=70,47 \\
\mathrm{SD}=6,00 \\
\mathrm{~S}^{2}=36,00\end{array}$ & 3,05 & 1,6705 & $\begin{array}{c}\text { Ha diterima, } \\
\text { Ho ditolak }\end{array}$ \\
\hline
\end{tabular}

Dari data distribusi $\mathrm{t}$ diperoleh $\mathrm{t}$ tabel $=1$,6705. sedangkan berdasarkan perhitungan diperoleh $t_{\text {hitung }}=3,05$ sehingga harga $t_{\text {hitung }}>t_{\text {tabel }}(3,05>1,6705)$. Dengan demikian kriteria pengujian hipotesis $t_{\text {hitung }}>t_{\text {tabel }}$ terpenuhi. Artinya $\mathrm{H}_{0}$ ditolak, Ha diterima yang berarti dapat disimpulkan bahwa hasil belajar kimia siswa yang diajarkan dengan model pembelajaran kooperartif tipe make a match pada pokok bahasan Koloid.

Berdasarkan perhitungan gain ternormalisasi pada kedua kelas, disimpulkan bahwa pada kelas eksperimen terdapat kategori gain tinggi sebanyak 23 siswa, gain sedang sebanyak 9 siswa, sedangkan gain rendah tidak ada. Sedangkan pada kelas kontrol terdapat kategori gain tinggi sebanyak 5 siswa, gain sedang sebanyak 27 siswa, gain rendah juga tidak ada. Data ini diperoleh dari lampiran 27 dan 29. Dimana untuk menentukan kriteria gain adalah $\mathrm{g}>0,7$ tinggi; $0,3<\mathrm{g}<$ 0,7 sedang; $\mathrm{g}<0,3$ rendah, maka dapat disajikan data gain pada tabel 3

Tabel 3. Data Rata-Rata Gain Kelas Eksperimen dan Kelas
\begin{tabular}{|l|l|}
\hline \multicolumn{1}{|c|}{ Kelas } & \multicolumn{1}{c|}{ Data } \\
\hline Eksperimen & $\sum X=21,78$ \\
& $\frac{\mathrm{X}}{\mathrm{X}}=0,68$ (kriteria gain sedang) \\
& $\mathrm{S}^{2}=0,085$ \\
& $\mathrm{~S}=0,0072$ \\
\hline Kontrol & $\sum X=19,78$ \\
& $\mathrm{X}=0,62$ (kriteria gain sedang) \\
& $\mathrm{S}=0,088$ \\
& $\mathrm{~S} \quad=0,0078$ \\
\hline
\end{tabular}

Untuk melihat peningkatan hasil belajar kimia siswa kelas eksperimen dan kelas kontrol dilihat dari rata-rata gain ternormalisasi kelas eksperimen dan kelas kontrol dikali 100\%. Data peningkatan hasil belajar siswa kelas eksperimen dan kelas kontrol disajikan pada tabel 4 di bawah ini.

\section{Tabel 4. Peningkatan Hasil Belajar Kimia Siswa Kelas Eksperimen Dan Kelas Kontrol}

\begin{tabular}{|c|c|}
\hline Kelas Eksperimen & Kelas Kontrol \\
\hline 0,68 & 0,62 \\
\hline $68 \%$ & $62 \%$ \\
\hline
\end{tabular}

Berdasarkan tabel diatas dapat dilihat bahwa peningkatan hasil belajar kimia siswa kelas eksperimen lebih tinggi dari pada hasil belajar kimia siswa kelas kontrol. 


\section{Pembahasan}

Berdasarkan hasil analisa data diperoleh bahwa sebelum diberikan perlakuan yang berbeda kepada kedua kelas sampel diperoleh bahwa rata-rata hasil belajar kimia siswa kelas eksperimen 27,81 \pm 7,21 dan setelah diberikan penerapan model pembelajaran kooperatif tipe make a match diperoleh rata-rata hasil belajar kimia siswa sebesar 76,88 $\pm 5,70$. Sedangkan untuk siswa kelas kontrol sebelum diberikan perlakuan diperoleh rata-rata hasil belajar kimia sebesar 22,03 $\pm 6,70$ dan setelah diberikan pembelajaran konvensional diperoleh hasil belajar 70,47 $\pm 6,00$. Untuk menghitung uji hipotesis ini digunakan uji t satu pihak, yaitu uji t pihak kanan, perhitungan harga $\mathrm{t}_{\text {hitung }}=3,05$ kemudian dikonsultasikan $\mathrm{t}_{(0,05)}\left(\mathrm{n}_{1}+\mathrm{n}_{2}-2\right)$ pada $\alpha=0,05$ maka secara interpolasi diperoleh $t_{\text {hitung }}>t_{\text {tabel }}$ yaitu 3,05 $>1,667139$. Maka hipotesis alternatif Ha diterima dan Ho ditolak. Artinya hasil belajar siswa dengan pengajaran menggunakan model pembelajaran kooperatif tipe make a match lebih tinggi daripada pengajaran konvensional. Peningkatan atau gain hasil belajar kimia siswa kelas eksperimen sebesar $68 \%$ sedangkan untuk kelas kontrol sebesar 62\%. Selisih perbedaan peningkatan hasil belajar siswa pada kelas eksperimen dengan kelas kontrol adalah $68 \%$ $-62 \%=6 \%$.

Penelitian sebelumnya yang menggunakan pembelajaran yang sama yaitu pembelajaran Make A Match yang dilakukan oleh Utomo (2010) persentase hasil belajar sebesar 60,3\%. Sedangkan penelitian lain yang dilakukan Ratna (2009) diperoleh persentase peningkatan hasil belajar sebesar $75,2 \%$.

Berdasarkan hasil penelitian saya dengan model pembelajaran make a match hasil belajar siswa meningkat dengan persentase sebesar 68\%, dapat dikatakan bahwa dengan menggunakan pembelajaran Make A Match meningkatkan hasil belajar siswa.

\section{Kesimpulan}

Berdasarkan hasil penelitian yang telah dilakukan maka dapat diambil kesimpulan yaitu :

1. Hasil belajar siswa yang diajarkan dengan model pembelajaran kooperatif tipe make a match lebih tinggi daripada hasil belajar siswa yang menggunakan pembelajaran konvensional pada pokok bahasan Koloid.

2. Peningkatan hasil belajar kimia siswa pada pembelajaran kooperatif tipe make a match sebesar $68 \%$ sedangkan peningkatan hasil belajar kimia siswa yang diajar dengan pembelajaran konvensional sebesar $62 \%$. Jadi, terdapat perbedaan peningkatan hasil belajar kimia siswa yang signifikan antara pembelajaran make a match dengan pembelajaran konvensional. Besarnya perbedaan peningkatan hasil belajar kimia siswa adalah $6 \%$.

\section{Referensi}

Arikunto, S., (2002), Dasar-Dasar Evaluasi Pendidikan, Rineka Cipta, Jakarta.

Arianti, Y., (2011), Pengaruh Model Learning Game Terhadap Motivasi Dan Hasil Belajar Siswa Dalam Pembelajaran Kimia di Kelas X SMK Pada Pokok Bahasan Tata Nama Senyawa Kimia, Skripsi, FMIPA, UNIMED, Medan.

Ayu, SP, (2010). Penerapan Cooperatif Learning Tipe Make A Match Untuk Meningkatkan hasil Belajar Siswa Kelas VII Dalam Pembelajaran Teknologi Informasi Dan Komunikasi, Jurnal Pendidikan Ilmu Komputer UPI, Hal 15-16

De Porter, B., Readon, M, dan Singer-Norie Sarah, 2007, Quantum Teaching, Kaifa: Bandung. Djamarah, S. B. dan Zain,A., (2006), Strategi Belajar Mengajar, Rineka Cipta, Jakarta.

Dwi Suyanti,R., (2010), Strategi Pembelajaran Kimia, Graha ilmu, Yogyakarta. 
Dwiyanti, L. A., (2010), Pengaruh Penerapan Model Pembelajaran Kooperatif Tipe STAD dengan Menggunakan Pendekatan Problem Possing Berbasis Web Terhadap Hasil Belajar Kimia Siswa, Skripsi, FMIPA, UNIMED, Medan.

Ginting, I., (2010), Pengaruh Pendekatan Kontruktivisme Dengan Model Pembelajaran Kooperatif Tipe Think Pair Share (Berbagi-Berpikir-Berpasangan) Terhadap Hasil Belajar Kimia Siswa Pada Pokok Bahasan Lambang Unsur Dan Rumus Kimia, Skripsi, FMIPS, UNIMED, Medan.

Hamalik, O., (2001), Perencanaan Pengajaran berdasarkan Pendekatan Sistem, Penerbit Bumu Aksara, Bandung.

Kuncoro, L., (2009), http://lennykuncoro.wordpress.com/2009/03/29/make-a-match/_accessed Februari-April 2011).

Lie, A., (2002). Cooperative Learning, Mempraktekkan Cooperative Learning di Ruang-ruang Kelas. Grasindo, Jakarta.

Mulyarsih, (2010), Peningkatkan Prestasi Belajar IPS Melalui Model Pembelajaran Kooperatif Make A Match Pada Siswa Kelas IV SDN Harjowinangun 01, Tersono Batang, Jurnal Kependidikan Dasar, Volume 1 Hal 97-105

Ratna, S., (2009), Upaya Meningkatkan Minat Belajar Matematika Siswa Kelas VIII SMP Negeri 1 Jetis Bantul Dengan Model Cooveratif Learning Tipe Make A Match, Skripsi, FKIP, UNY, Yogyakarta

Saiful, (2011), http://s4iful4min.blogspot.com/.../metode-make-match-tujuan-persiapandan.html (accassed Februari-April 2011)

Silitonga,P.M., (2011), Statistika: Teori dan Aplikasi dalam Penelitian, Graha Ilmu, Yogyakarta

Slameto, (1988), Belajar dan Faktor-faktor yang Mempengaruhinya, Bina Aksara, Jakarta.

Sudjana, (2005), Metode Statistika, Tarsito, Bandung.

Suprijono, A., 2009, Cooperatif Learning, Pustaka Belajar, Yogyakarta.

Sutresna, N., (2007). Cerdas Belajar Kimia Untuk Kelas X SMA, Grafindo Media Pratama, Bandung

Suyanti, R. D., (2010), Strategi Pembelajaran Kimia, Penerbit Graha Ilmu, Jakarta

Tarmizi, (2008), http://tarmizi.wordpress.com/2008/12/03/make-a-match/_accessed FebruariApril 2011)

Tritanto, (2009), Mendesain Model Pembelajaran Inovatif-progresif: Konsep, Landasan, dan Implentasinya pada Kurikulum Tingkat Satuan Pendidikan (KTSP), Prenada Media Grup, Jakarta

Utomo, T.S., (2010), Pengaruh Persepsi Siswa Tentang Metode Make A Match Dan Motivasi Belajar Terhadap Hasil Belajar Ekonomi Pada Siswa Kelas X SMA Negeri 1 Wuryantoro T.A. 2009/2010, Skripsi, FMIPA, UMS, Semarang.

Winkel, (1996), Psikologi Pengajaran, Gramedia Widiasarana Indonesia, Jakarta. 